UDC: $582.682 .2: 482.477 .2: 631.811 .98: 631.532 / .535$

DOI: $10.15587 / 2519-8025.2017 .105504$

\title{
OPTIMIZATION OF SOME ELEMENTS OF CULTIVATION TECHNOLOGY OF ORNAMENTALS IN THE NORTH-EASTERN PART OF FOREST-STEPPE OF UKRAINE
}

\author{
(C) V. Tokman
}

\begin{abstract}
Досліджено фактори, які впливають на ефективність коренеутворення у живців декоративних рослин (Buxus sempervirens L., Thuja occidentalis L.). Встановлена доиільність використання Rhizopon AA poeder для укорінення стеблових живців T. осcidentalis в умовах дрібнодисперсного зволоження. Рекомендовано для вирощування садивного матеріалу із закритою кореневою системою використовувати субстрат: торф, пісок, перегній у співвідношенні 1:1:0,5
\end{abstract}

Ключові слова: Buхиs sempervirens, Thuja occidentalis, регулятори росту, живцювання, укорінення, фумap, Rhizopon

\section{Introduction}

Nowadays, Buxus sempervirens and Thuja occidentalis are wide spread ornamentals in Ukraine. Both of them are typically grown in evenly moist, well-drained loam soils (e. g., sand-clay mixture) in full sun to part shade. The plants prefer soils with a $\mathrm{pH}$ of slightly acidic to slightly alkaline, tolerates somewhat wide range of soils and some dry conditions. Root rot can also be a problem in poorly-drained and less mulch soils.

Production of cultivating propagation material of the ornamental plants, for example on the farms in Ukraine, does not provide the growing needs of the gardeners. One of the main reasons is that the existing technologies of their reproduction are ineffective, they are rather time-consuming, and thus it represses the spread of new species and their forms in landscape architecture [1].

To obtain a good, healthy plant, various soil media, growth regulators, vary the timing of cuttings, the size of the cuttings and the conditions for further rooting can be optimized [2]. Propagation by stem cuttings is the most commonly used method to propagate many woody ornamental plants. Stem cuttings of many favorite shrubs are quite easy to root. Typically, stem cuttings of tree species are more difficult to root. In addition, each species of plants requires an individual selection of phytohormones, which will be optimal for using under certain conditions [3]. Therefore, in order to improve the plant material, the study aimed at optimising propagation and adventitious rooting techniques of stem cuttings Buxus sempervirens and Thuja occidentalis was conducted.

\section{Literature review}

Vegetative propagation is the most common method used in commercial production of many garden. In many species, vegetative propagation depends on the regeneration ability and growing of adventitious roots on overground parts of the plants [4]. The efficiency of vegetative propagation is also significantly influenced by the environment in the propagation house, such as temperature, quality of the used substrate, and the air humidity. Other important aspects include the care for mother plants, selection of appropriate term for taking the cuttings, and quality of storage of the plant material before the cuttings are taken [5].
It is known that for vegetative propagation methods it is preferably to harvest cuttings from spring to late fall. But the best time is April-May, that is the time when energy of their growth increases [4]. In the process of propagation, hereditary properties of the plant organism are important, in this case each species and even form reacts differently to the terms of cutting [6]. Depend on environmental conditions of research different terms of propagation were recommended.

The analysis of recent research and publications shows that studies on cultivating plant propagation materials $B$. sempervirens and $T$. occidentalis contain insufficient information about the influence of the type of substrate and its acidity, terms of plant cutting and modern biologically active compounds on the process of rhizogenes of cuttings [7]. The best substrate for rooting cuttings of some ornamentals is a mixture consisting of peat with acidity $\mathrm{pH}$ 5.2-6.0 [8].

Processes of plant growth and development are controlled by various phytohormones produced by the plant. In particular, a number of phytohormones regulate formation of the plant root system: cytokinins, auxins, ethylene, gibberellins, abscisic acid and brassinosteroids [9]. Using bioactive compounds for the plant propagation helps researchers considerably solve the problem of increasing planting material production [10]. It was proved that physiologically active substances are analogues of phytohormones or their antagonists that can change the hormonal balance of plants in the desired direction. The regeneration of the root system sufficiently depends on auxins, and they interact with other endogenous phytohormones. Formation of the root system does not depend on the content of auxins and inhibitors in the plant organism but it depends on their correlation [11].

Using phytohormones in optimal concentrations and expositions, roots on cuttings are formed earlier and in greater numbers, the callus formation is stimulated, and after rooting the shoot growth of the treated cuttings significantly enhances. Generally, biologically active substances are used for cuttings of difficult-to-root species.

Phytohormones have a direct (interacting with other hormones and molecules) influence on the regenerative ability of the plant [4]. Auxins play an important role in controlling the growth and development of the 
plants [12]. The most commonly used auxin is synthetic 3 -indolylbutyric acid (IBA), which proves to be the most effective hormone promoting the production of adventitious roots compared to natural indolyl-3- acetic acid (IAA) [13]. For successful propagation by cuttings it is also necessary to select the correct time for taking the cuttings, which closely relates to the content of natural phytohormones. One of the commercially available products is Rhizopon stimulator, which is distributed to the market in multiple forms (solution, powder, gel, tablets) and also in different concentrations. The active component of this stimulator is synthetic auxin IBA and NAA /synthetic auxin is $\alpha$-naphthylacetic acid [5].

The data of Chezh researchers showed that stimulators prove good effect for some ornamentals, but they say about no efficiency it for Buxus. For example, using Rhizopon AA powder $1 \%$ for Buxus sempervirens «Winter beaty» rooting percentage was $92,9 \%, 2 \%-88.6$, $0.5 \%-87.1$, and control (without any hormones) $-92.9 \%$. For species «Globosa» control $97.9 \% 1 \%-92,5 \%$, Rotundifolia -88.9 and $96.8 \%$ respectively [5].

Other researchers underlined that rooting of Buxus hyrcana is slow and they also set up positive effect of growth regulators on rooting of semi-hardwood cuttings in greenhouse condition, but the best percentage was obtained of 6-benzylaminopurine (BAP) comparing with NAA and IBA [14].

In Ukraine, there is a tendency toward the increase in the share of the planting material production of ornamental species with the closed root system, which requires development and justification of the cultivation technology. Thus, it is necessary to study some elements of cultivating technology of planting materials under conditions of optimal hydration.

\section{Aim and research problems}

The aim was to improve the techniques and methods of artificial propagation of some species of ornamental plants, particularly B. sempervirens and $T$. occidentalis under conditions of artificial fog.

Research problems:

1. Set up the best substrate for cuttings.

2. Find out the optional terms for propagation.

3. Figure out the more effective growth regulators for the best rooting.

\section{Materials and methods}

Experimental research was carried out in the laboratory of the educational and practical center of Sumy National Agrarian University during 2014-2015.

The objects of the study were ornamental species: B. sempervirens and T. occidentalis, which were stocked with a 'butt'. For cuttings uterine plants of 20-year-old ornamental species were used.

The given study was a part of scientific theme "Improvement of existing and development of new technologies of cultivating planting material of the ornamental and berry crops" (the number of Ukrainian state registration 0116U003341). The scheme of research is: factor A - type of the substrate: control (peat+humus (1:1)), peat+sand+humus (1:1:1), peat+ +sand (1:1); factor B - acidity of the substrate: control (sand+peat $(\mathrm{pH} 3.5)$ ), sand+perlite+peat $(\mathrm{pH} 3.5)$, sand+peat ( $\mathrm{pH}$ 6.0); factor $\mathrm{C}$ - terms of plant cutting: control (April), June and August; factor D - plant growth regulators (phytohormones): control (water), fumar, kornevin or Rhizopon AA poeder $1 \%$; factor E structure of the substrate: control (peat+sand (1:1)), peat+sand+humus (1:1:0.5). Fumar is unparalleled universal high-performance plant growth stimulator, dimethyl amino ester of fumaric acid (producer is Research and production association «Agrodar», Dnepr, Ukraine). Kornevin is also a unique biostimulator, on sale it can be found in the form of a powder. The composition includes indolyl-butyric acid (IMC) at a concentration of $5 \mathrm{~g} / \mathrm{kg}$. But comparing with Rhizopon it contents also potassium and phosphorus, as well as macro elements: manganese, molybdenum, etc.

The peat of the Lithuanian company DOMOFLOR ( $\mathrm{pH} 6.0$ and 3.5) was used for conducting the research.

In March, the rooted cuttings of the studied species were transplanted into pots of the volume of 1.1 liters.

To conduct the research the methods of application of phytohormones into the open and protected ground were used [15]. The statistical data processing was performed with the method of analysis of variance [16] and the computer programs.

\section{Results of the research}

Until recently, the vegetative propagation for obtaining the planting material of ornamental species was rarely used, but due to the intensive development of selection, the role of this method in propagating ornamentals has significantly increased. However, it is based on the capacity of plants to restore the root system. An important condition for the regeneration of the root system is the optimal composition of the substrate (Fig. 1).

The study of the effect of substrates on rooting has showed that cuttings take root differently on different substrates, and the best substrate among the studied types for the root formation is the mixture of peat DOMOFLOR ( $\mathrm{pH}$ 6.0) and sand in the ratio 1:1, but roots of cuttings $T$. occidentalis are not formed on the substrates containing humus. It may be due to the fact that the substrate contains humus excessively enriched with nutrients, especially nitrogen, which at the stage of rooting adversely affects the process of hizogenes. The surplus of nutrient elements in some substrates caused burns of the roots and even yellowing of $B$. sempervirens tops of cuttings.

The maximum rooting of cuttings $B$. sempervirens was observed in the variant with the substrate mixture of sand and peat, and the smallest - in the control variant (peat+sand+humus).

When the mixture of sand and peat was used, the indicator of the rooting of cuttings (T. occidentalis) marked $16 \%$, which is 8 times more than in the control plants. While using peat and humus, the above-mentioned index was within the control norm $\left(\mathrm{LSD}_{05} 4.71\right)$.

The process of rhizogenes of cuttings is influenced not only by the type of the substrate but biological properties of the studied species. For example, in 2015 while using peat and sand, the rooting rate of cuttings B. sempervirens marked $95 \%$, and T. occidentalis $-16 \%$. 
At the stage of rhizogenes of cuttings, the substrate should hold sufficient moisture and be manageable for the roots, which were formed, to grow and develop.

At the first phase of vegetative propagation, i.e during rooting cuttings, the digestion of nutrient elements from the substrate probably does not occur. However, in this period, they are very sensitive both to the shortage and the excessive concentration of hydrogen cations, aluminum, iron, manganese, sodium in the soil solution [17].

One of the important conditions for the regeneration of the root system is the substrate with the optimal level of acidity. However, the discrepancy between the acidity of the substrate and biological properties of plants negatively affecs the the root formation process in stem cuttings (Table 1).

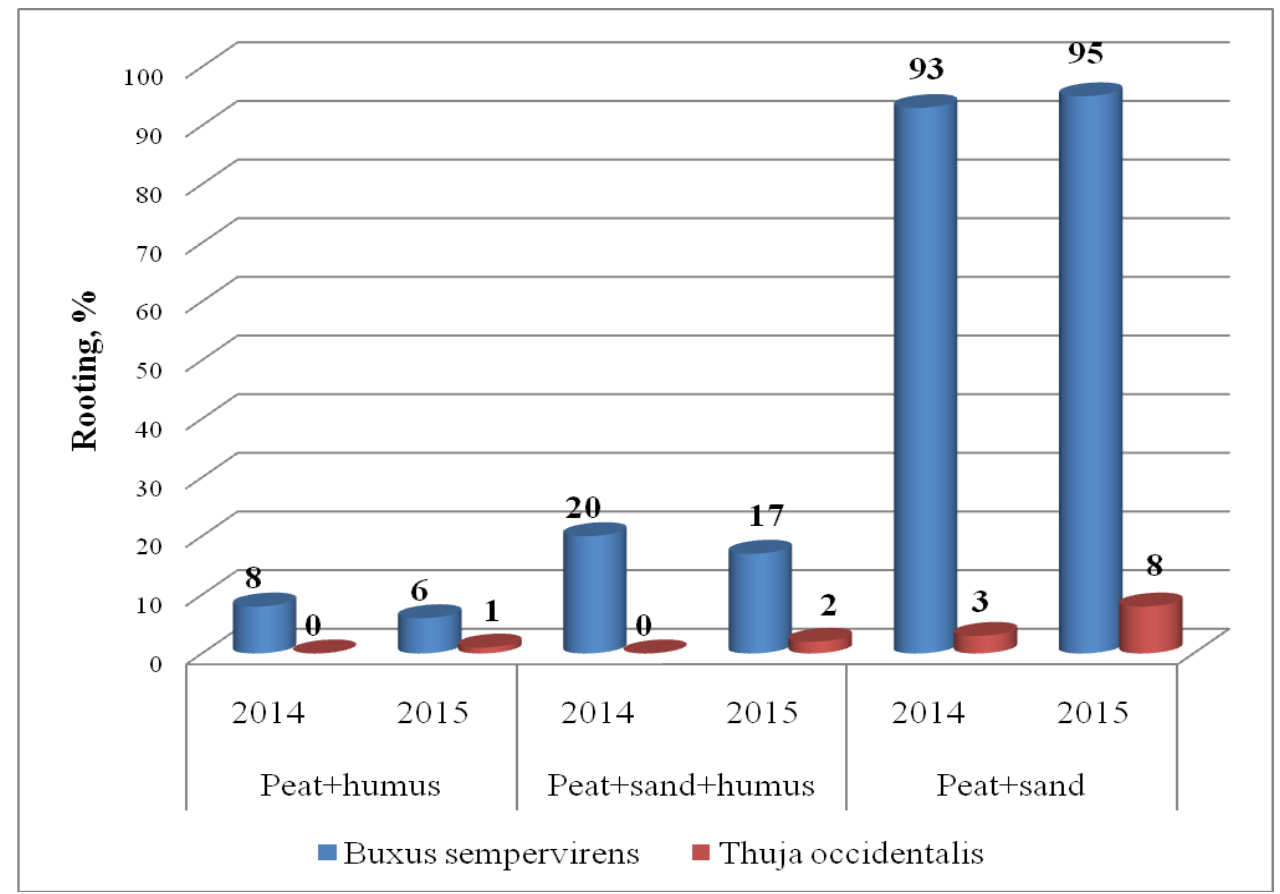

Fig. 1. The effect of the substrate type on the rooting process of cuttings, $\%$

Table 1

Effects of acidity of the substrate on the rooting process of cuttings

\begin{tabular}{|c|c|c|c|c|c|}
\hline \multirow{2}{*}{ No. } & \multirow{2}{*}{ Type of substrate } & \multicolumn{2}{|c|}{ B. sempervirens } & \multicolumn{2}{|c|}{ T. occidentalis } \\
\hline & & Rooting, \% & \pm before control & Rooting, $\%$ & \pm before control \\
\hline 1 & Control (sand+peat $(\mathrm{pH} \mathrm{3,5))}$ & 35 & - & 0 & - \\
\hline 2 & Sand+perlite+peat $(\mathrm{pH} \mathrm{3,5)}$ & 30 & -5 & 0 & 0 \\
\hline 3 & Sand+peat (pH 6.0) & 95 & +60 & 16 & +16 \\
\hline & $\mathrm{LSD}_{05}$ & 8,37 & & 3,35 & \\
\hline
\end{tabular}

According to the research, the rooting of cuttings (B. sempervirens) is affected by the acidity of the substrate. However, in the control variant the rooting rate is $35 \%$, while the acidity of the substrate is $\mathrm{pH} 6.0-95 \%$. Thus, high acidity of the substrate adversely affects the process of rhizogenes of cuttings $T$. occidentalis [1]. The maximum rooting rate of stem cuttings of ornamental plants was observed in the substrate with neutral acidity. Statistical analysis of the indicators of the research has revealed differences between the options $\left(\mathrm{LSD}_{05} 8.37\right.$ and 3.35).

The research results have revealed significant differences between the effect of the acidity of the substrate and biological properties of ornamental plants on the process of rhizogenes of cuttings of the above- mentioned species. Thus, it have proved that rooting cuttings is influenced not only by the acidity of the substrate but biological properties of the studied pecies.

Therefore, for the normal plant growth and development it is important to create and maintain a certain hydrogen ion concentration $(\mathrm{pH})$ in a nutrient solution, which must meet biological characteristics of the species. All this must be considered while applying the technology of cultivating plant propagation material.

The development of decorative plant propagation requires intensification of technological processes and significant improvement of farming cultivation of planting materials of ornamental species. Thus, the choice of optimal time for plant cutting enhances the efficiency of the propagation technology, as shown in Table 2. 
Table 2

Effects of terms of plant cutting on the process of rhizogenes of cuttings

\begin{tabular}{|c|c|c|c|c|c|}
\hline \multirow{2}{*}{ No. } & \multirow{2}{*}{$\begin{array}{l}\text { Terms of plant cut- } \\
\text { ting }\end{array}$} & \multicolumn{2}{|c|}{2014} & \multicolumn{2}{|c|}{2015} \\
\hline & & Rooting, \% & \pm before control & Rooting, \% & \pm before control \\
\hline \multicolumn{6}{|c|}{ B. sempervirens } \\
\hline 1 & Control (April) & 93 & - & 95 & - \\
\hline 2 & June & 96 & +3 & 97 & +2 \\
\hline 3 & August & 91 & -2 & 94 & -1 \\
\hline & $\mathrm{LSD}_{05}$ & 4,0 & & 3,16 & \\
\hline \multicolumn{6}{|c|}{ T. occidentalis } \\
\hline 1 & Control (April) & 16 & - & 19 & - \\
\hline 2 & June & 3 & -13 & 4 & -15 \\
\hline 3 & August & 0 & -16 & 0 & -19 \\
\hline \multicolumn{2}{|r|}{$\mathrm{LSD}_{05}$} & 3,3 & & 6,73 & \\
\hline
\end{tabular}

The results of research devoted to the rooting of plant cuttings $B$. sempervirens indicate that the terms of plant cuttings do not affect the process of rhizogenes.

When vegetative propagation was used, $16 \%$ of cuttings T. occidentalis formed root in April that is 5.3 times more than in the first experimental variant (June). Minimum rooting rate was recorded in the variants where cutting was done in August. A similar tendency of rooting cuttings of this species also was observed in 2015.

The research has proved significant differences between the variants, and there was considered that propagation of $T$. occidentalis by stiff stem cuttings should be used in mid-April.
Probably, different regenerative capacity of cuttings of the studied species harvested in different phenological phases is caused by a varying activity of growth promoters as well as growth inhibitors.

The optimal time for cutting of ornamental species or forms is defined by the calendar period and the degree of woodiness of shoots, indicating biological properties of plants. Thus, cutting at the best time allows to purposefully regulate physiological processes in the plant organism and increase the efficiency of technological operations.

Using biologically active compounds is an effective agrotechnical method, which improves technologies of propagating planting material (Table 3 ).

Table 3

Effects of plant growth regulators on the rooting process of cuttings, \%

\begin{tabular}{|c|c|c|c|c|c|}
\hline \multirow{2}{*}{ No. } & \multirow{2}{*}{ Variant of the experiment } & \multicolumn{2}{|c|}{2014} & \multicolumn{2}{|c|}{2015} \\
\hline & & Rooting, $\%$ & \pm before control & Rooting, \% & \pm before control \\
\hline \multicolumn{6}{|c|}{ B. sempervirens } \\
\hline 1 & Control (water) & 93 & - & 95 & - \\
\hline 2 & Fumar & 90 & -3 & 92 & -3 \\
\hline 3 & Kornevin & 94 & +4 & 94 & -1 \\
\hline & $\mathrm{LSD}_{05}$ & 3,78 & & 3,4 & \\
\hline \multicolumn{6}{|c|}{ T. occidentalis } \\
\hline 1 & & Control (water) & 15 & - & 19 \\
\hline 2 & & Fumar & 28 & +13 & 34 \\
\hline 3 & & $\begin{array}{l}\text { Rhizopon } A A \\
\text { poeder }\end{array}$ & 73 & +58 & 81 \\
\hline & $\mathrm{LSD}_{05}$ & 7,16 & & 10,27 & \\
\hline
\end{tabular}

On average, the results of two-year research have proved that the change of the natural hormonal balance of cuttings B. sempervirens under the influence of phytohormones does not affect the rooting process compared with plant cutting without them ( $\operatorname{LSD}_{05} 3.78$ and 3.4).

With vegetative propagation of the abovementioned species under conditions of fine hydration, excellent results can be obtained even without using physiologically active compounds.

According to some researchers [10], rhizogenes activity of cuttings depends on the auxin concentration. Due to its content in the plant organism the effect of stimulation or inhibition becomes possible. However, its high concentration stimulates the rooting process. It is synthesized in the cones of growing shoots. Since in shoots auxin is always transported down, then its molecules are gradually accumulated at the lower cut of the cutting and contribute to the root formation.

Probably, a slight disruption of living systems functioning of stem cuttings $T$. occidentalis under the influence of exogenous physiologically active substances, in particular Rhizopon AA poeder, affects the auxin concentration in the the lower part of the cutting, which significantly influences the root system formation. For example, when using the compound in 2015, the rooting rate was $81 \%$, that is $62 \%$ and $47 \%$ more compared with the control variant and fumar.

Thus, it has been proved that the use of Rhizopon $A A$ poeder for treating stem cuttings of the studied species (T. occidentalis) in comparison with fumar 
makes it possible to maximize the rooting percentage and the output of planting material. Therefore, it is recommended to use plant growth regulators.

According to the research results, $B$. sempervirens belongs to 'easy-to-root' species, and T. occidentalis - to difficult-to-root ones.
With vegetative propagation, the treatment of cuttings with biologically active compounds increases their rooting percentage, significantly reduces terms of plant rooting, which ensures the development of a strong root system, and positively affects the plant growth and development (Table 4).

Table 4

Biometric indicators of rooted cuttings

\begin{tabular}{|c|c|c|c|c|c|c|}
\hline \multirow{3}{*}{ No. } & \multirow{3}{*}{$\begin{array}{l}\text { Variant of the experi- } \\
\text { ment }\end{array}$} & \multicolumn{5}{|c|}{ Biometric indicators of plants } \\
\hline & & \multirow{2}{*}{$\begin{array}{l}\text { number of } \\
\text { roots of } 1 \text { or- } \\
\text { der, pcs. }\end{array}$} & \multicolumn{4}{|c|}{ weight, $\mathrm{g}$} \\
\hline & & & root system & $\begin{array}{c} \pm \text { before con- } \\
\text { trol }\end{array}$ & aerial part & $\begin{array}{c} \pm \text { before con- } \\
\text { trol }\end{array}$ \\
\hline \multicolumn{7}{|c|}{ B. sempervirens } \\
\hline 1 & Control & 4 & 0,61 & - & 2,02 & \\
\hline 2 & Fumar & 5 & 0,97 & $+0,36$ & 2,13 & $+0,11$ \\
\hline \multicolumn{2}{|r|}{$\%$ before control } & 125 & 159,0 & & 105,4 & \\
\hline 3 & Kornevin & 5 & 1,26 & $+0,65$ & 2,41 & $+0,39$ \\
\hline \multicolumn{2}{|r|}{$\%$ before control } & 125 & 206,6 & & 119,3 & \\
\hline \multicolumn{2}{|r|}{$\mathrm{LSD}_{05}$} & & 0,26 & & 0,2 & \\
\hline \multicolumn{7}{|c|}{ T. occidentalis } \\
\hline 1 & Control & 4 & 0,32 & & 2,4 & \\
\hline 2 & Fumar & 8 & 0,51 & $+0,19$ & 2,95 & $+0,55$ \\
\hline \multicolumn{2}{|r|}{$\%$ before control } & 200 & 159,4 & & 122,9 & $+0,63$ \\
\hline 3 & Rhizopon AA poeder & 10 & 0,79 & +47 & 3,03 & \\
\hline \multicolumn{2}{|r|}{$\%$ before control } & 250 & 246,9 & & 126,3 & \\
\hline \multicolumn{2}{|r|}{$\mathrm{LSD}_{05}$} & & 0,11 & & 0,24 & \\
\hline
\end{tabular}

The cuttings of $B$. sempervirens ornamental species have formed 4-5 roots. According to the study, cuttings $T$. occidentalis in the control sample have formed 4 roots of the first order, it is 2 and 2.5 times less than in the experimental variants, when fumar and Rhizopon AA poeder were used.

The treatment of cuttings (T. occidentalis) with plant growth regulators (fumar, Rhizopon AA poeder) more significantly affects root formation of order 1 , compared with the other type (B. sempervirens).

When using kornevin, the weight of the root system of plants $B$. sempervirens reached $1.26 \mathrm{~g}$, it is $0.29 \mathrm{~g}$ and $0.65 \mathrm{~g}$ less than in other variants where the cuttings were soaked in fumar and water $\left(\mathrm{LSD}_{05} 0.26\right)$.

Some growth regulators significantly influenced not only the wieght of the root system, but the aerial part of the studied species. For example, in the control variant, the weight of the aerial part of plants B. sempervirens was $2.02 \mathrm{~g}$, it is $0.1 \mathrm{~g}$ and $0.39 \mathrm{~g}$ less than in the variants, when biologically active compounds were used ( $\mathrm{LSD}_{05}$ 0.26).

The research results suggest that the use of biologically active compounds influences the biometric indicators of the rooted cuttings $T$. occidentalis.

The weight of the root system in the control variant was $0.32 \mathrm{~g}$, it is $0.19 \mathrm{~g}$ and $0.47 \mathrm{~g}$ less than in the other vari- ants, when fumar and Rhizopon AA poeder were used. The treatment of cuttings with physiologically active compounds significantly influenced the root growth $\left(\mathrm{LSD}_{05} 0.11\right)$.

When using Rhizopon AA poeder, the root system of the cuttings of the studied species was more fibrous in comparison with the control group and fumar.

Treating cuttings of the above-mentioned species with root stimulants influenced not only the weight of the root system but aerial parts as well. For example, the weight of the aerial parts of plants (T. occidentalis) was within 2.4-3.03 g and significant differences were observed between the variants $\left(\mathrm{LSD}_{05} 0.24 \mathrm{~g}\right)$.

Thus, plant growth regulators influence the growth and development of stem cuttings of ornamentals. In the control variants, biometric indicators of the plants proved to be minimal in comparision with the research options. The most effective compounds are kornevin and Rhizopon AA poeder, which significantly change not only the growth and development of the root system but the aerial parts of ornamental species.

According to the standarts for planting materials, their quality is determined by certain biometric parameters of development of aerial and root systems.

The research results have proved that the growth and development of ornamentals is significantly influenced by the substrate type (Table 5). 
Table 5

Effects of substrate type on the growth and development of plants

\begin{tabular}{|c|c|c|c|c|c|c|c|}
\hline \multirow[b]{2}{*}{ No. } & \multirow[b]{2}{*}{ Variant } & \multicolumn{2}{|c|}{ Length, $\mathrm{cm}$} & \multicolumn{4}{|c|}{ Weight, $\mathrm{g}$} \\
\hline & & aerial part & growth & aerial part & root system & $\begin{array}{c} \pm \text { before } \\
\text { control }\end{array}$ & plants \\
\hline \multicolumn{8}{|c|}{ B. sempervirens } \\
\hline 1 & Peat+sand & 13,0 & - & 2,7 & 1,37 & - & 4,07 \\
\hline 2 & Peat+sand+humus & 20,2 & 7,8 & 3,79 & 7,13 & $+5,76$ & 10,92 \\
\hline & $\mathrm{LSD}_{05}$ & 1,24 & & & 1,26 & & \\
\hline \multicolumn{8}{|c|}{ T. occidentalis } \\
\hline 1 & Peat+sand & 18,7 & 1.2 & 11,6 & 2,1 & - & 13,7 \\
\hline 2 & Peat+sand+humus & 25,9 & 8,1 & 17,3 & 4,9 & $+2,8$ & 22,2 \\
\hline & $\mathrm{LSD}_{05}$ & 1,02 & & & 0,87 & & \\
\hline
\end{tabular}

In the control sample, the aerial part of plants $B$. sempervirens was $13.0 \mathrm{~cm}$; it is $7.2 \mathrm{~cm}$ lower than the experimental variant (LSD05 1.24). When using the mixture of peat, sand and humus, the plant growth of the aerial part of this species was $7.8 \mathrm{~cm}$, and in the control sample there was no growth.

The study indicates that the substrate type influences not only the size of the aerial parts but the mass of aerial and root systems of the above-mentioned species.

The weight of the root system in the control variant was $7.13 \mathrm{~g}$, that is $5.76 \mathrm{~g}$ less than in the variant with the mixture of peat and sand $\left(\mathrm{LSD}_{05} 1.26\right)$.

The total weight of the control plants was $4.07 \mathrm{~g}$, that is almost 2.7 times less compared with the use of peat, sand and humus.

In the control plants, biometric parameters of the species $B$ sempervirens were minimal compared with the other variant (peat+sand+humus).

The length of the aerial part of plants $T$. occidentalis in the research variant was $25.9 \mathrm{~cm}$, that is $138.5 \%$ more than in the control sample. The research results prove that the growth of the aerial part of T. occidentalis in the mixture of peat, sand and humus reached $8.1 \mathrm{~cm}$ and in the control sample $-1.2 \mathrm{~cm}$. The substrate type also significantly influenced on the mass of the plant root system of that sort, and its weight was within 11.6-17.3 g. Minimum weight of the root system of the above-mentioned plants was recorded for the control plants (sand+peat) and was $2.1 \mathrm{~g}$, it is 2.33 times less in comparison with the experimental variant (sand+peat+humus).

Thus, the maximum figures of biometric parameters of $B$. sempervirens and T. occidentalis were noted in the variant with the substrate of $\mathrm{t}$ mixture of sand, peat and humus.

Due to hereditary properties, the plants react specifically to conditions of their growth, particularly to using fertilizers. This demonstrates the need for developing a system of fertilization not for plants in general, but for certain plant species and forms - for their optimal growth and development under specific soil and climatic conditions.

\section{Conclusions}

The research of vegetative propagation of $B$. sempervirens and T. occidentalis has proved that:

1) for cultivating planting material with the closed root system, it is recommended to use the substrate containing the peat DOMOFLOR ( $\mathrm{pH}$ 6.0), sand and humus in the ratio $1: 1: 0.5$, which positively influences the plant growth and development of the studied species;

2) under conditions of the mist, B. sempervirens can be successfully propagated from April to August by stem cuttings; propagation of $T$. occidentalis by stem cutting should done in April;

3 ) for cultivating plant propagation material of T. occidentalis it is recommended to use the root stimulant (Rhizopon AA poeder).

\section{References}

1. Melnik, A. V. Osoblyvosti rozmnozhennya Juniperus comminis L. steblovymy zhyvcyamy v umovax pivnichno-sxidnoyi chastyny Lisostepu Ukrayiny [Peculiarities of propagating Juniperus communis L by stem cuttings in the north-eastern part of foreststeppe of Ukraine] [Text] / A. V. Melnik, V. S. Tokman // Visnyk Sumskoho natsionalnoho ahrarnoho universytetu. Seriia: Ahronomiia i biolohiia [Herald of Sumy National Agrarian University. Series: Agronomy and Biology]. - 2016. - Vol. 2, Issue 31. P. 8-12.

2. Balabak, O. A. Biolohichni osoblyvosti adventyvnoho koreneutvorennia u steblovykh zhyvtsiv dernu spravzhnoho (Cornus mas L.) [Biological properties of adventitious root formation in stem cuttings of the real turf (Cornus mas L.)] [Text] / O. A. Balabak // Ahrobiolohiia [Agrobiology]. - 2012. - Vol. 9 (96). - P. 99-103.

3. Ponomarenko, S. P. Rehuliatory rostu roslyn na osnovi N-oksydiv pokhidnykh pirydynu [Plant growth regulators on the basis of N-oxides of pyridine derivatives] [Text] / S. P. Ponomarenko. - Kyiv: Tekhnika, 1999. - 272 p.

4. Hartman, H. T. Plant propagation principles and pracrices [Text] / H. T. Hartman et. al. - New Jersey: Prentice Hall, 2002. $-880 \mathrm{p}$.

5. Salas, P. Evaluation of different types of rooting stimulators [Text] / P. Salas, H. Saskova, J. Mokrickova, T. Litschmann // Acta Universitatis Agriculturae et Silviculturae Mendelianae Brunensis. - 2013. - Vol. 60, Issue 8. - P. 217-228. doi: 10.11118/ actaun201260080217

6. Torchik, V. I. Osobennosti adventivnogo korneobrazovaniya u steblevih cherenkov nekotorih sadovih form roda Juniperus v zavisimosti ot strokov zagotovki [Peculiarities of adventitious root formation of stem cuttings of some garden forms of Genus Juniperus in dependence on harvesting time] [Text] / V. I. Torchik, A. F. Kelko // Trudy Belarusskogo gosudarstvennogo tehnicheskogo universiteta [Works of Belarusian State Technological University]. - 2016. - Vol. 1 (83). - P. 216-219. 
7. Rubtsov, A. V. Deyaki aspekty vdoskonalennya pryskorenoho rozmnozhennya maloposhyrenykh ekzotiv ta vysokodekoratyvnykh kultyvariv u pivdenno-stepovomu rehioni Ukrainy [Some aspects for improvement of accelerated reproduction of not widespread exotics and highly ornamental cultivars in the southern steppe region of Ukraine] [Text] / A. V. Rubtsov // Visnyk Dnipropetrovskoho universytetu. Biolohiia. Ekolohiia [Visnyk of Dnipropetrovsk University. Biology. Ecology]. - 2008. - Vol. 2, Issue 16. - P. 141-146.

8. Mauer, V. M. Dekoratyvne rozsadnytstvo z osnovamy nasinnytstva [Production of ornamental nursery crops with basics of seeding] [Text] / V. M. Mauer. - Kyiv: Aristey, 2006. -273 p.

9. Makrushyn, M. M. Fiziolohiia roslyn [Plant Physiology] [Text] / M. M. Makrushyn, E. M. Makrushyna, N. V. Petrosian, M. M. Melnykov; M. M. Makrushyn (Ed.). - Vinnitsa: New Book, 2006. - 416 p.

10. Sokolov, T. A. Dekorativnoe rastenievodstvo. Drevovodstvo [Ornamental plant production. Arboriculture] [Text] / T. A. Sokolov. - Moscow: ACADEMA, 2004. - 345 p.

11. Zlobin, Yu. A. Kurs fiziolohii i biokhimii roslyn [The course of Plant Physiology and Biochemistry] / Yu. A. Zlobin. Sumy: Publishing House "University Book", 2004. - 464 p.

12. Šebánek, J. Fyziologie vegetativního množení dřevin [Physiology of vegetative propagation of woody species] [Text] / J. Šebánek. - Brno: Mendelova zemědělská a lesnická univerzita, 2008. - 60 s.

13. Pop, T. Auxin control in the formation of adventitions roots [Text] / T. Pop, D. Pamfi, C. Bellini // Notulae Botanicae Horti Agrobotanici Cluj-Napoca, 2011. - Vol. 39, Issue 1. - P. 307-316.

14. Kaviani, B. Propagation, micropropagation and cryopreservation of Buxus hyrcana Pojark., an endangered ornamental shrub [Text] / B. Kaviani, N. Negahdar // South African Journal of Botany. - 2017. - Vol. 111. - P. 326-335. doi: 10.1016/ j.sajb.2017.04.004

15. Kazakova, V. N. Metodika ispyitaniy regulyatorov rosta i razvitiya rasteniy v otkryitom i zaschischennom grunte [Methods of testing plant growth and development regulators in the open and protected soil] [Text] / V. N. Kazakova et. al. - Moscow: Russian State Agrarian University, 1990. - 56 p.

16. Dospekhov, B. A. Metodika polevogo opyta [Methods of field experiences] [Text] / B. A. Dospekhov. - Moscow: Agropromizdat, 1985. - $351 \mathrm{p}$.

17. Hospodarenko, H. M. Ahrokhimiia [Agrochemistry] / H. M. Hospodarenko. - Kyiv: National Scientific Center "IAE", 2010. $-400 \mathrm{p}$.

Рекомендовано до публікації д-р біол. наук Скляр В. Г. Дата надходження рукопису 15.05.2017

Volodymyr Tokman, PhD, Associate Professor, Department of Gardening and Forestry, Sumy National Agrarian University, Gerasyma Kondratyeva str., 160, Sumy, Ukraine, 40021

E-mail: tokman2017@i.ua

УДК 595.132:574.2

DOI: $10.15587 / 2519-8025.2017 .105511$

\title{
ЗАЛЕЖНІСТЬ ГУСТИНИ ПОПУЛЯЦÏ DITYLENCHUS DESTRUCTOR THORNE ВІД ВОЛОГОСТІ І ТЕМПЕРАТУРИ ГРУНТУ В УМОВАХ ПІВНІЧНОГО СХОДУ УКРАЇНИ
}

\author{
(C) К. І. Бородіна, Р. А. Білаш
}

Установлено, щзо паразитична активність стеблових нематод (Ditylenchus destructor Thorne) викликає пошкодження картоплі та визначає ступінь його шкідливості у північно-східних регіонах України. Вивчено вплив двох абіотичних факторів - температури і вологості - на розвиток даних нематод. Саме вони є важливими лімітуючими екологічними чинниками збільшення густоти популяції та агресивності виду в умовах Північного Сходу Украӥни

Ключові слова: Ditylenchus destructor, густина популяції, температура, вологість, абіотичні фактори, кореляція, регресія

\section{1. Вступ}

В Україні картоплю вирощують численні сільськогосподарські підприємства, фермерські господарства і біля 80 \% населення, проте врожайність цієї культури залишається досить низькою в порівнянні 3 країнами, де розвинене картоплярство. Наприклад, на досить великій частині площ тривалий час урожай бульб залишається на рівні 10-12 т/га і лише на невеликих площах збирають 20-40 т/га. Хвороби і шкідники є однією з основних причин значного недобору врожаю картоплі, зниження їі якості.
У групі патогенних організмів найбільш небезпечним для картоплярства $є$ нематоди. Інтенсивність розвитку шкідника залежить не тільки від чисельності цист у грунті, але й від факторів, що мають підсилити розвиток і спричинити епіфітотію. Такими факторами $\epsilon$ особливості генотипу рослин, вплив зовнішнього середовища, беззмінне вирощування на малородючих кислих грунтах, пізні строки посадки, використання для посадки бульб з ознаками виродження, низький рівень агротехніки і хімічної меліорації грунтів.

Велику шкоду картоплярству України спричиняє стеблова нематода картоплі Ditylenchus destructor 